УДК 621.311.68:631.563.2:66.047.3.086

DOI https://doi.org/10.15673/swonaft.v84i1.1871

\title{
ІНІЦІЮВАННЯ МЕХАНОДИФУЗІЙНОГО РЕЖИМУ ВОЛОГОВІДВЕДЕННЯ В ПРОЦЕСАХ ЗНЕВОДНЕННЯ РОСЛИННОЇ СИРОВИНИ
}

\author{
Яровий І.І., канд. техн. наук, Алі В.П., аспірант \\ Одеська національна академія харчових технологій
}

\begin{abstract}
Анотація. Стаття містить результати експериментальної частини дослідження, щуо проводиться за загальним напрямом впровадження технологій адресної доставки енергї (АДЕ) в типових процесах харчової та переробної промисловості. В роботі визначено мету та засоби досягнення результатів, методи проведення дослідження, приведено аналіз отриманих результатів.

Основний зміст роботи полягає в дослідженні умов та обмежень при яких можливо та доцільно ініціювання та підтримка в стабільному стані механодифузійного режиму вилучення вологи при зневодненні вологих матеріалів з капілярно-пористою структурою. Визначено актуальність та доцільність використання ефекту механодифузії в процесах зневоднення сировини рослинного походження та вологих матеріалів з схожою будовою внутрішніх шарів. Обгрунтовано необхідність використання додаткових рушійних сил для інтенсифікації процесу вологовідведення з поверхні частинок матеріалу. Зокрема запропоновано використати для ичього принции фільтраційного способу сушіння. Визначено основні переваги комбінування енергопідведення за допомогою мікрохвильового електромагнітного поля та вологовідведення способом фільтраційного сушіння. Експериментально доведено принципову можливість та ефективність такої комбінаиіï.

Описано причини обрання даного напряму досліджень, місие дослідження в системі наукової діяльності наукового колективу, зв'язки з іншими дослідженнями. Обтрунтовано актуальність дослідження, обрано конструкиію дослідного стенда, способи проведення експерименту та методи оцінки отриманих результатів. Приведено структурну схему та порядок проведення експерименту, обтрунтовано способи та методику збору інформації про хід експерименту. Описано приничипи керування прочесом енергопідводу та процесом вологовідведення. Надано обгрунтування обраного способу впливу на процес зневоднення, та доцільність його реалізації в стрічковій сушильній установці. Визначено модельну сировину та параметри процесу, щуо підлягають контролю в ході експерименту. Надано зразки графіків залежностей між основними параметрами процесу, отримані в ході експерименту. Виконано оцінку отриманих результатів. Визначено залежності кінетики прочесу від питомої величини енергопідведення. Надано приниипову схему удосконаленого сушильного модуля стрічкової мікрохвильової сушильної установки з реалізацією режиму механодифузійного вологовидалення. Приведено висновки, щзодо завершеного етапу дослідження.
\end{abstract}

Ключові слова: електромагнітні джерела енергії, технологія адресної доставки енергії, механодифузія, мікрохвильові апарати, мікрохвильове сушіння, фільтраційне сушіння, комбіновані способи сушіння, сушіння рослинної сировини, інноваційні способи сушіння.

\section{INITIATION OF MECHANODIFFUSION MODE OF MOISTURE REMOVAL IN PROCESSES OF DEHYDRATION OF VEGETABLE RAW MATERIALS}

\author{
Yarovy I.I., Ph.D., Ali V.P., graduate student \\ Odessa National Academy of Food Technologies
}

Abstract. The article contains the results of the experimental part of the study, which is conducted in the gen-
eral direction of the introduction of targeted energy delivery technologies (TED) in typical processes of the food and
processing industries. The purpose and means of achievement of results, methods of carrying out of research are
defined in work, the analysis of the received results is resulted.
The main content of the work is to study the conditions and constraints under which it is possible and appropri-
ate to initiate and maintain in a stable state the mechanodiffusion regime of moisture extraction during dehydration
wet materials with capillary-porous structure.The relevance and expediency of using the effect of
mechanodiffusion in the processes of dehydration of raw materials of plant origin and wet materials with a similar 


\section{Одеська національна академія харчових технологій ЕНЕРГОЕФЕКТИВНІСТЬ. РЕСУРСОЗБЕРІГАЮЧІ ТА ЕКОЛОГІЧНО-БЕЗПЕЧНІ ЕНЕРГОТЕХНОЛОГІї}

structure of the inner layers are determined. The necessity of using additional driving forces to intensify the process of moisture removal from the surface of material particles is substantiated. In particular, it is proposed to use the principle of the filtration drying method. The main advantages of combining energy supply with the help of a microwave electromagnetic field and moisture removal by the method of filtration drying are determined. The fundamental possibility and efficiency of such a combination have been experimentally proved.

The reasons for choosing this area of research, the place of research in the system of scientific activity of the research team, connections with other research are described. The relevance of the study is substantiated, the design of the experimental stand, the methods of the experiment and the methods of evaluation of the obtained results are chosen. The structural scheme and procedure of the experiment are given; the methods and techniques of collecting information about the course of the experiment are substantiated. The principles of control of the energy supply process and the moisture removal process are described. The substantiation of the chosen way of influence on dehydration process, and expediency of its realization in the tape drying installation is given. The model raw materials and process parameters to be controlled during the experiment are determined. Samples of graphs of dependences between the main process parameters obtained during the experiment are given. The evaluation of the obtained results is performed. The dependences of the process kinetics on the specific value of energy supply are determined. The schematic diagram of the advanced drying module of the belt microwave drying unit with the implementation of the mechanodiffusion dehumidification mode is given. Conclusions are given on the completed stage of the study.

Key words: electromagnetic energy sources, technology of targeted energy delivery, mechanodiffusion, microwave devices, microwave drying, filtration drying, combined drying methods, drying of vegetable raw materials, innovative drying methods.

Вступ. Одним з основних напрямів наукових досліджень, що проводяться науковцями кафедри процесів, обладнання та енергетичного менеджменту ОНАХТ є пошук, адаптація та впровадження в процеси переробки харчової сировини, інноваційних технологій підводу енергії з метою ініціювання та/або інтенсифікації процесів її (сировини) переробки. Однією з найбільш перспективних технологій енергопідводу є використання мікрохвильового електромагнітного випромінювання для об'ємного, безконтактного нагрівання вологих матеріалів. Завдяки особливостям взаємодії високочастотного (мікрохвильового, в даному випадку) електромагнітного поля з вологою, що міститься в матеріалі, можна реалізувати високоінтенсивне, «вибіркове» нагрівання саме тих областей де міститься велика частина вологи, та залишити менш нагрітими ті області де вологи менше. Деталізуючи даний принцип, можна стверджувати, що основною вирізняльною особливістю даного способу підводу енергії є ії вплив саме на вологу (молекули води) що міститься в обробляємій речовині. Даний механізм підводу енергії можливо використовувати в різних процесах: сушінні, екстрагуванні, випарюванні, ініціюванні та пригніченні мікробактеріологічних процесів.

Для означення області використання цільового енергетичного впливу на процеси за допомогою надвисокочастотних (НВЧ) електромагнітних хвиль використовується термін АДЕ - адресна доставка енергії [1]. Сам принцип нагрівання вологих матеріалів НВЧ випромінюванням відомий давно, проте його використання і на сьогодні є досить обмеженим внаслідок декількох причин: технічної складності реалізації установок, високої вартості потужного генеруючого обладнання, відносно невисокого к.к.д. та ресурсу генераторів НВЧ електромагнітного поля, значної (порівняно з іншими енергоносіями) вартості електричної енергії та дещо упередженого ставлення суспільства до мікрохвильових технологій в цілому.

Більшість $з$ вищеозначених причин є суто технічними (дитячими хворобами) технології електромагнітного енергопідведення, деякі можна мінімізувати або обійти. Наприклад: проблему дефіциту потужності можна вирішити одночасним використанням декількох генераторів або використавши конвеєрну конструкцію з багатьма окремими зонами впливу, проблема складності технічної реалізації установок АДЕ легко вирішується використанням типових компонентів та використанням мікропроцесорних керуючих приладів, що на сьогоднішній день, знімає і проблему високої вартості. Окремо слід звернути увагу на проблему енергоефективності, для технологій АДЕ саме цей аспект має стати «точкою прориву». Потенціально, саме ці технології можуть стати найбільш енергоефективними способами ведення тепломасообмінних процесів, пов'язаних з впливом на вологі матеріали. Взаємодія електромагнітного поля з молекулами води і результуючий вплив цієї взаємодії на рослинний матеріал на рівні клітин та капілярів відкриває новий рівень цільового впливу та контролю у великій кількості типових процесів харчової та переробної галузей. Механізм та особливості реалізації принципів АДЕ є зоною постійного наукового інтересу в роботах науковців кафедри $[2,3]$.

Актуальність. В цілому, актуальність пошуку та впровадження нових, енергоефективних способів вологовидалення в технологічних процесах переробки сировини та виготовлення харчових продуктів не підлягає сумніву [4,5]. Сучасні технології сушіння, наприклад, базуються, в основному, на конвективних технологіях теплопереносу, і вже після достатньо інтенсивного нагрівання всього об'єму матеріалу ініціюються

Наукові праці, Том 84, випуск 1

Scientific Works, Volume 84, Issue 1 


\section{Одеська національна академія харчових технологій ЕНЕРГОЕФЕКТИВНІСТЬ. РЕСУРСОЗБЕРІГАЮЧІ ТА ЕКОЛОГІЧНО-БЕЗПЕЧНІ ЕНЕРГОТЕХНОЛОГІї}

процеси масопереносу вологи, інтенсивність та повнота яких в значній мірі залежать саме від величини енергопідводу. Найбільш енергомарнотратними конвективні технології сушіння є на етапі досушування, коли внаслідок росту термічного опору частково висушеного матеріалу при сталому енергопідведенні значно зменшується вологовідведення і більша частина підведеного тепла витрачається на нагрівання вже майже сухих поверхневих шарів матеріалу - об'єкту сушіння. Цей енергопідвід, при його сталій величині, може стати фатальним для поверхневих структур матеріалу. Але і при зменшенні енергопідводу пропорційно кількості залишкової вологи матеріалу (або відповідно будь якому іншому алгоритму) ефект буде дуже обмежений - так як період досушування розтягнеться в часі а інтегральні витрати енергії на сушіння зростуть до економічно недоцільних величин.

Таким чином, сам принцип впливу на процес вилучення вологи з матеріалу вимагає заміни. Найбільш реальною альтернативною є технологія АДЕ, основною перевагою якої є принципово інший принцип енергопідведення. Нагріваючи безпосередньо вологу, що міститься в матеріалі, установки з АДЕ не витрачатимуть енергію на нагрівання сухої речовини матеріалу, що в свою чергу створює реальні підстави отримання високопродуктивних та енергоефективних режимів вологовидалення.

Сама ж технологія АДЕ, як і будь яка інша, ніяк не гарантує автоматичного отримання енергоефективного та високопродуктивного режиму вологовидалення. Для досягнення якісного результату необхідно дослідити, та відтворити в деталях процес взаємодії НВЧ електромагнітного поля з вологою у кожних типових умовах (вологому матеріалі), так як суттєвими є саме обмеження, що накладаються на дану взаємодію саме конкретним типом вологого матеріалу.

Яскравим прикладом такого випадку є саме рослинна сировина, яка в більшості випадків представляє собою складну багатошарову волокнисто - капілярну структуру. Капілярна структура в даному випадку і представляє найбільш суттєві обмеження, що накладаються на процес вологовиведення, так як процес масоперенесення в межах капілярів та між шарами матеріалу в більшій мірі визначається цією структурою ніж процесами нагрівання вологи НВЧ полем.

Мета та зміст досліджень. Зважаючи на широкий спектр можливого використання технологій АДЕ, та значну кількість досліджень, необхідних для розробки кожної з реалізацій технології, дослідження проводяться за найбільш перспективними напрямками. Одним з таких напрямків є інтенсифікація процесів сушіння рослинної сировини шляхом поєднання технології АДЕ з іншими способами та технологіями сушіння.

Важливим досягненням наукового колективу кафедри, на шляху створення високопродуктивних та енергоефективних технологій сушіння, $є$ аналітичне обгрунтування [6] і фізична демонстрація механодифузійного режиму (МДР) виведення вологи [7]. Реалізація даного режиму в промислових сушильних установках дозволить отримати апарати 3 принципово новим рівнем енергоефективності, так як на сьогодні механодифузійний режим вилучення вологи є єдиною перспективною технологією, що дозволяє видаляти вологу 3 матеріалу без її повного випаровування та мінімально впливаючи на сам матеріал.

Метою даного дослідження $є$ апробація механодифузійного режиму видалення вологи в процесі сушіння рослинної сировини. Попередні спроби створення умов для ініціювання МДР вологовиведення при сушінні зернових, з використанням АДЕ, дозволили встановити ряд обставин, що визначають первинні умови такої реалізації. Зокрема величина окремих частинок рослинного матеріалу повинна бути достатньою для того, щоб містити кількість вологи, необхідну для підтримання МДР, а поверхня частинок має бути відносно гладкою, щоб викинуту на поверхню частинок вологу можна було видалити без ії̈ випарювання.

Зміст дослідження полягав у створенні умов для експериментальної демонстрації фізичних проявів механодифузійного ефекту. За планом дослідження проведено серію дослідів по визначенню умов для ініціації та подальшого підтримання механодифузійного режиму вологовидалення. В результаті дослідження, на прикладі бобів гороху, визначено доцільний режим енергопідведення, умови виникнення режиму та отримано відеофіксацію проявів МДР.

Результати експериментальних досліджень. Відповідно теорії АДЕ, найбільший ефект від ініціювання МДР можливо отримати при обробці матеріалів з розвиненою капілярно - пористою системою і структурою частинок у вигляді послідовності оболонок. Рослинні матеріали з подібною структурою частинок повинні продемонструвати переваги технології АДЕ найбільш явно, що пов'язано з ефектом об'ємного нагріву і відсутністю ефекту зростання термічного опору оболонки частинок на етапі досушування.

Актуальний цикл дослідження був спрямований як на вивчення способів ініціювання МДР так і на перевірку можливості інтенсифікації процесу вологовидалення шляхом комбінування АДЕ з таким способом вилучення вологи як фільтраційне сушіння.

Для проведення експериментальної частини використано боби гороху з початковою вологістю в діапазоні 20-26\% в.в.. Дослідження процесу проводилося на спеціально зібраному стенді. Загальний вигляд і структурна схема і стенду показані на рис. 1.

Суть експерименту полягає в фізичному моделюванні процесу впливу на вологий матеріал MX випромінювання в сушильній камері, для досягнення ефекту МДР вологовиведення та наступного продування 
Одеська національна академія харчових технологій

\section{ЕНЕРГОЕФЕКТИВНІСТЬ. РЕСУРСОЗБЕРІГАЮЧІ ТА ЕКОЛОГІЧНО-БЕЗПЕЧНІ} ЕНЕРГОТЕХНОЛОГІї

нагрітого матеріалу потоком атмосферного повітря з метою механічного вилучення капельної вологи 3 поверхні частинок нагрітого матеріалу. Завдяки аналітичному аналізу та попереднім дослідженням колег, було зрозуміло, що для ініціювання МДР доцільно використовувати відносно короткі (десятки секунд) імпульси енергопідводу та значно менші (декілька секунд) періоди продування матеріалу потоком повітря. Сам процес обробки являв собою послідовну обробку касети зі зразком вологого матеріалу мікрохвильовим випромінюванням і подальше продування касети атмосферним повітрям.

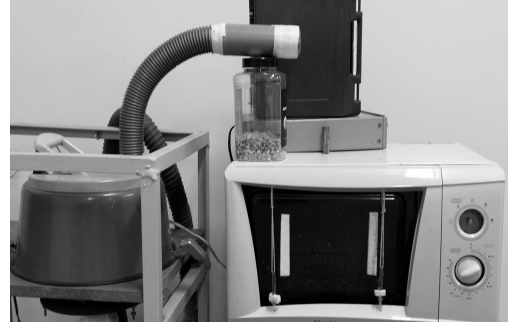

a)

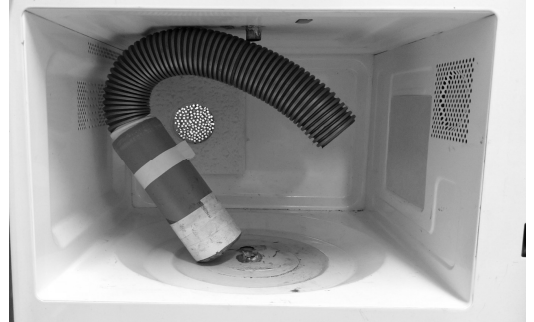

б)

а) загальний вигляд в режимі продування касети; б) нагрівання касети МХ полем

\section{Рис. 1 - Дослідний стенд для дослідження механодифузійного режиму вологовидалення}

Передбачається, що тривалість впливу МХ випромінюванням і продувки встановлюються у відповідності до фізичних розмірів (габаритів сушильної камери) стрічкової багатозонної сушильної установки.

Експериментально визначено, що для ініціювання МДР, необхідні наступні умови: частинки вологого матеріалу повинні мати достатню кількість вологи, (18-20\% в.в.), і бути піддані впливу АДЕ при питомій потужності генератора 3-4 кВт/кг, протягом 40-60 с. При такому впливі на поверхні частинок (зерен) утворюються викиди вологи у вигляді окремих крапель, які при подальшому включенні вентилятора продувки слід здути з поверхні, тобто видалити без повного випаровування. При наступних циклах обробки тривалість впливу АДЕ слід скоротити до 15-30 с, а на етапі досушування до 10-15 с, щоб уникнути перегріву і пошкодження матеріалу. Тривалість продувки може становити 5-10 с, в залежності від швидкості повітряного потоку. В проведеному дослідженні швидкість потоку повітря становила 6-7 м/с, шо визначалось конструктивними параметрами вентилятора і є характерним для фільтраційного сушіння, згідно роботі [8].

Алгоритм проведення експерименту включав фазу попереднього нагріву, і 3-5 циклів по 5-6 впливів комбінації АДЕ і продувки. На початку і в кінці кожного досліду, а також між циклами, проводилось зважування касети зі зразком матеріалу на аналітичних вагах. За зменшенням ваги касети визначалась кількість видаленої вологи. Контрольне вимірювання початкової і кінцевої вологості матеріалу проводилося вологоміром «Wille-66». Для керування послідовністю циклів і реєстрації параметрів процесу, дослідний стенд обладнано системою автоматичного управління.

Для отримання явного, візуального підтвердження наявності механодифузійного режиму вилучення вологи проведено серію експериментів з використанням швидкісної відеофіксації. Циліндричний формат касети (рис. 2б) прийнято для отримання масово - значимого потоку вологи. Гіпотеза полягала в тому, що під час продування тонкого шару матеріалу (моделі рухомого шару стрічкової сушарки) краплі вологи на поверхні частинок не встигають утворити значний обсяг, внаслідок чого візуально, практично не помітні. Якщо збільшити загальну площу поверхні частинок, що обдуваються потоком повітря в режимі фільтраційного сушіння, то в кінці траєкторії цього потоку, краплі вологи, відірвані від поверхні частинок, в результаті механодифузійного процесу, досягнуть візуально значимої величини. Для фіксації процесу видалення крапельної використовувалась швидкісна відеофіксація.

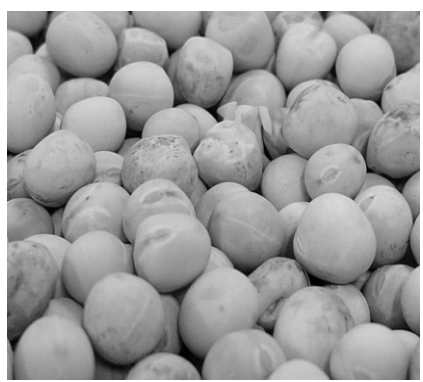

a)

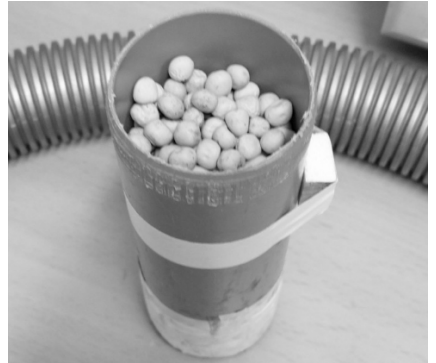

б)

а) вологий горох, б) циліндрична касета

Рис. 2 - Матеріал для дослідження

Наукові праці, Том 84, випуск 1

Scientific Works, Volume 84, Issue 1 
Одеська національна академія харчових технологій ЕНЕРГОЕФЕКТИВНІСТЬ. РЕСУРСОЗБЕРІГАЮЧІ ТА ЕКОЛОГІЧНО-БЕЗПЕЧНІ ЕНЕРГОТЕХНОЛОГІЇ

Проведено дослідження залежності кінетики вологовидалення від навантаження. Використовувалась наступна схема обробки: 60 с мх $+(6 * 5 *(10$ с мх +5 с фс $))$, всього 34 цикли ( 9 хв.).

Матеріал зразка-горох; вага зразка становила: 170/219/270 гр., відповідно питоме навантаження складало: 1,62 кВт/кг, 1,88 кВт/кг та 2,21 кВт/кг. Графіки отриманих залежностей представлені на рис. 3.

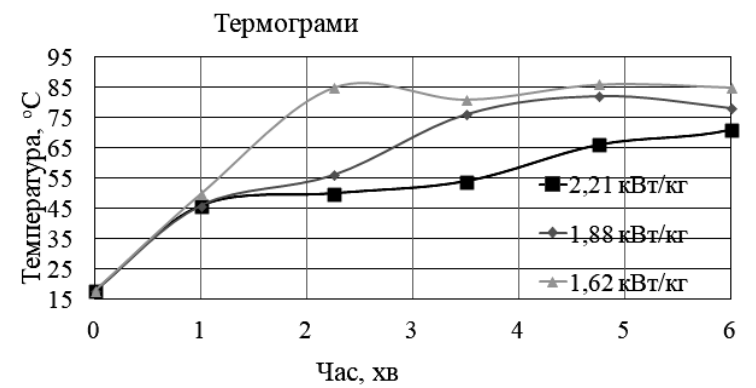

Динаміка зміни швидкості сушіння

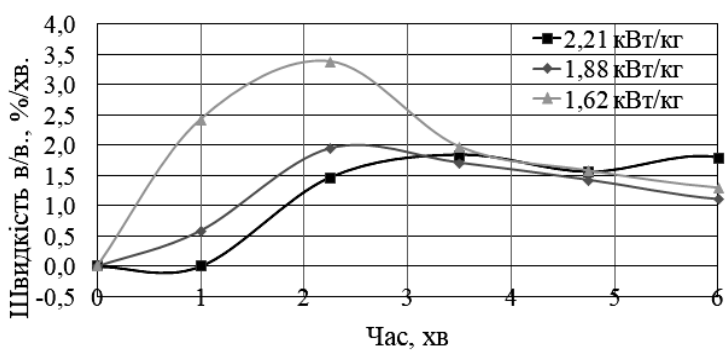

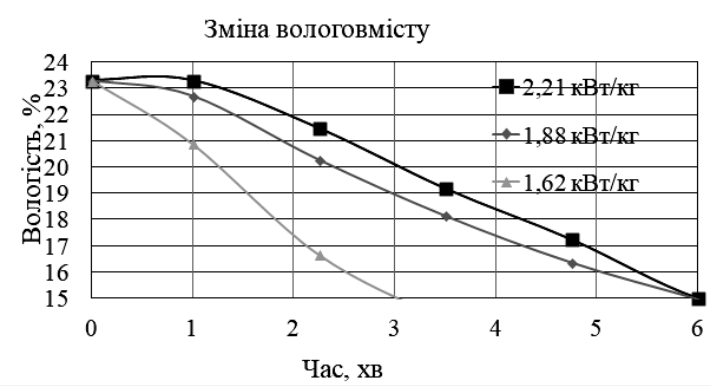

Залежність швидкості сушіння від вологості

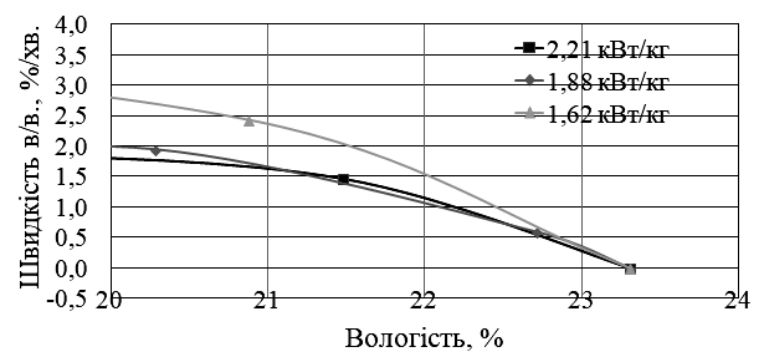

Рис. 3 - Кінетика процесу вилучення вологи при зміні величини навантаження камери нагріву

Для визначення впливу тривалості продувки (періоду фільтраційної сушки) на режим вилучення вологи проведено експерименти 3 тривалістю продувки 5, 10 і 15 с. В результаті отримано залежності, представлені на рис. 4.
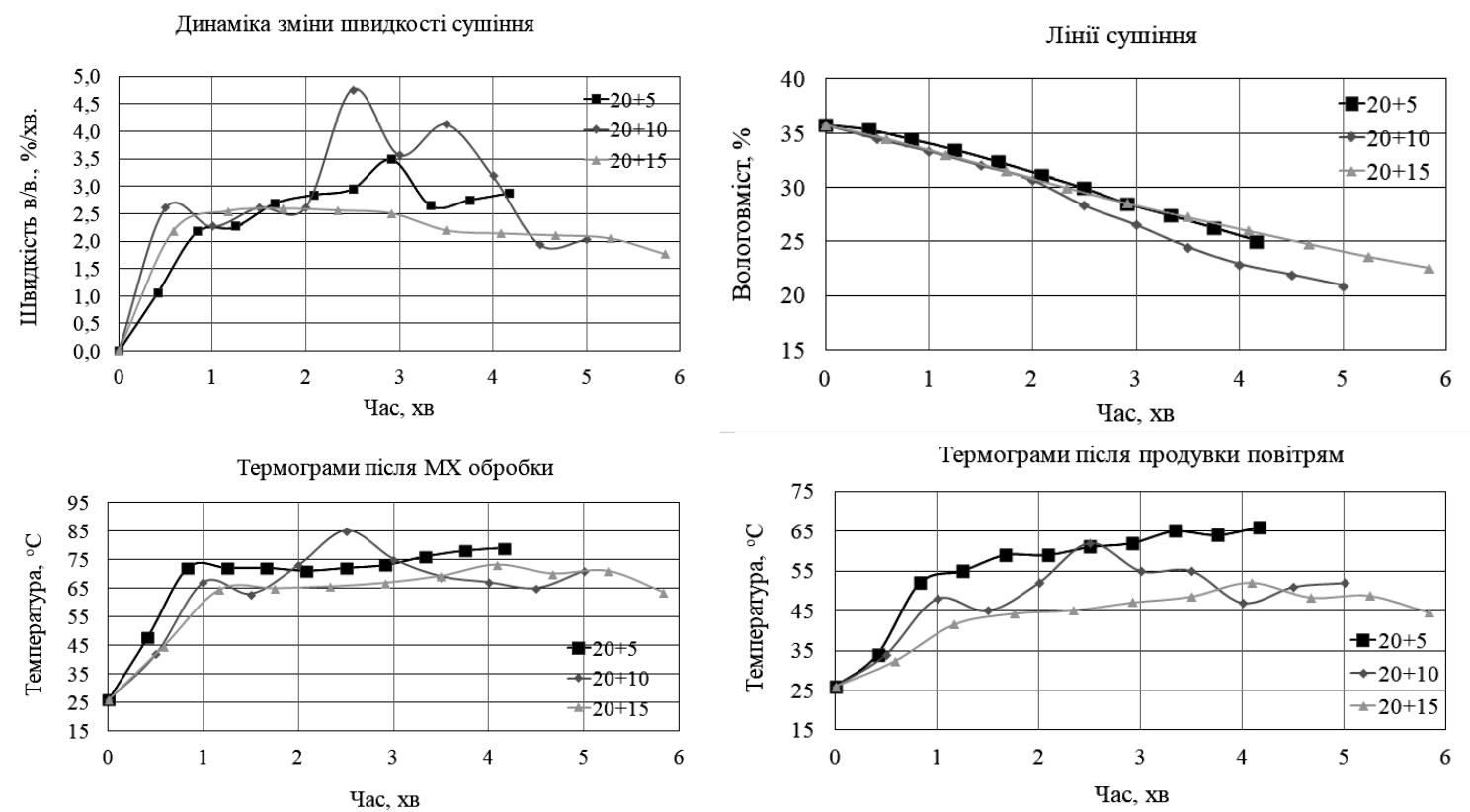

Рис. 4 - Кінетика процесу вилучення вологи при зміні тривалості фільтраційного періоду

Аналіз отриманих даних. Результати експериментів підтверджують основні показники процесу видалення вологи з рослинного матеріалу за умови використання технологій АДЕ як способу енергопідведення, отримано стійкий процес вилучення вологи при швидкостях 2,5 - 3,2 \%/хв.

В ході експериментів по візуалізації процесу механодифузії, як доказ можливості ініціації МдР вилучення вологи отримано серію відеороликів, що фіксує формування великих крапель води в момент продувки

Наукові праці, Том 84, випуск 1

Scientific Works, Volume 84, Issue 1 
Одеська національна академія харчових технологій

\section{ЕНЕРГОЕФЕКТИВНІСТЬ. РЕСУРСОЗБЕРІГАЮЧІ ТА ЕКОЛОГІЧНО-БЕЗПЕЧНІ}

ЕНЕРГОТЕХНОЛОГІї

шару вологого матеріалу (бобів гороху) попередньо обробленого в камері АДЕ. Експериментально встановлено, що тривалість продувки мало впливає на кількість витягнутої вологи. За отриманим відео можна зробити висновок, що основна маса вологи «здувається» 3 поверхні частинок на перших секундах продувки. Краплі вологи в ході продувки шару чітко видно на відеокадрі (рис. 5а).

В ході дослідження визначено основні технічні обмеження характерні для наявної камери МХ нагрівання і системи продувки шару сировини атмосферним повітрям. Запропоновано конструктивні зміни, доцільні для внесення в конструкцію сушильної установки кафедри. Конструкцію кожної МХ камери слід доповнити вентилятором продувки шару вологого матеріалу. Варіант такої модернізації зображений на рис. $5 б$.

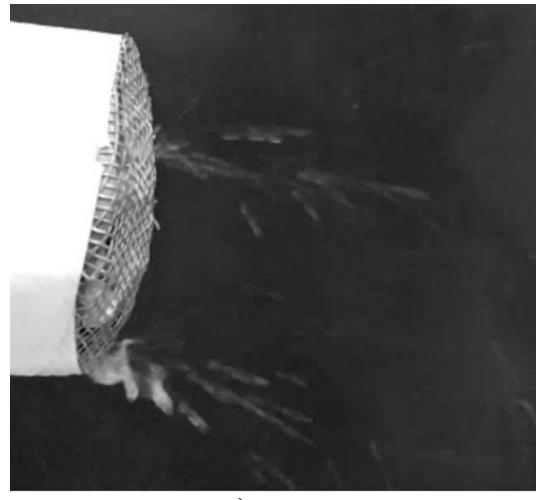

a)

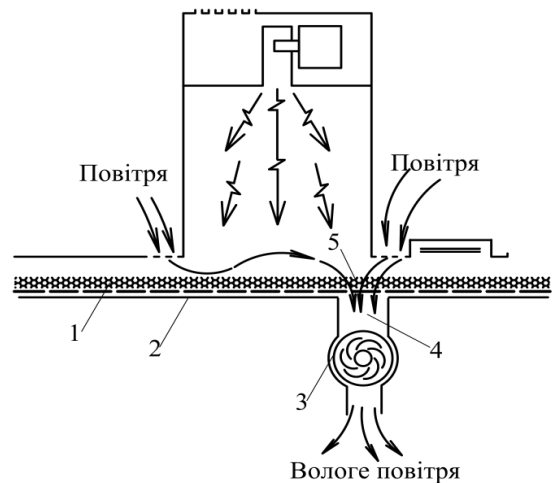

б)

а) відеокадр, щзо фіксує викид крапель води під час продування шару вологого матеріалу та після впливу МХ нагріву; б) вдосконалений сушильний модуль: 1 - шар вологого матеріалу, що рухається на сітчастій транспортерній стрічиі, 2 - металеве дно транспортного тунелю, 3 - вентилятор, 4 - патрубок для відведення повітряного потоку, 5 - ділянка фільтраційного сушіння

\section{Рис. 5 - Процес капельного вологовидалення після впливу МХ нагріванням}

Висновки. Отримані результати дозволяють доповнити раніше проведені дослідження по розробці технологій АДЕ інформацією щодо кінетики і технічних обмежень комбінованого способу вологовидалення, що поєднує технології АДЕ та фільтраційного сушіння.

Доведено більш високу ефективність даного способу в порівнянні з застосуванням тільки АДЕ.

Запропоновано для практичної реалізації конструкцію удосконаленого сушильного модулю, що реалізує даний комбінований спосіб вологовідведення.

\section{References}

1. Burdo, O.G., Terziev, S.G., Bandura, V.N. (2015). Principles of directed energy action in food nanotechnologies. Problems of regional energy, 1 (27), 79-85.

2. Burdo, O.G. (2005). Nanoscale effects in food production technologies. J Eng Phys Thermophys, 78, 90-96. https://doi.org/10.1007/s10891-005-0033-6

3. Burdo, O., Bandura, V., Zikov, A., Zozulyak, I., Levtrinska, J., Marenchenko, E. (2017). Development of wave technologies for intensification of heat and mass transfer processes. EA-Western European Journal of Enterprise Technologies, 4/11 (88), 34-42. https://doi.org/10.15587/1729-4061.2017.108843

4. Braginets, S., Rukhlyada, A., Bakhchevnikov, O., Pakhomov, V. (2018). Mathematical modeling of microwave-vacuum drying of vegetative mass. ENGINEERING FOR AGRICULTURAL COMPANY DEVELOPMENT 17th International Scientific Conference. Jelgava, May 23-25. https://doi.org/10.22616/erdev2018.17.n221

5. Arballo, J., \& Campañone, L., \& Mascheroni, R. (2010). Simulation of microwave drying of fruits. Drying technology, 28. 1178-1184. https://doi.org/10.1080/07373937.2010.493253

6. Burdo, O.G., Terziev, S.G., Bandura V.N., Yarovoy, I.I. (2016). Mechanodiffusion effect is a new phenomenon in heat and mass transfer. MMF thesis book. Minsk, Belarus, 224. https://www.itmo.by/doc/mif 15/Tom2.pdf

7. Bezbach, I., Yarovy, I. \& Voitenko, O. (2019). Combined methods of energy supply in the drying of vegetable raw materials. Scientific works, 83 (2), 71-77. https://doi.org/10.15673/swonaft.v2i83.1532

8. Atamanyuk, V., Mosyuk, M., Ivashchuk, O. and Zakharkiv, O. (2016). Kinetics of filtration drying of crushed miscanthus. Scientific Bulletin of NLTU of Ukraine, 26 (8), 257-264. https://doi.org/10.15421/40260840

Отримано в редакцію 15.06.2020

Прийнято до друку 30.09.2020
Received 15.06.2020

Approved 30.09.2020 